\title{
Limodissimin A: A New Dimeric Coumarin from Limonia acidissima
}

\author{
Ki Hyun Kim, Sang Keun Ha, ${ }^{+}$Sun Yeou Kim, ${ }^{+}$Sung Hoon Kim,,$+\underset{+}{ }$ and Kang Ro Lee \\ Natural Products Laboratory, College of Pharmacy, Sungkvinkwan Lniversity, Suwon $4+0-7+6$, Korea \\ "E-mail: krleeiáskhu ackr \\ -Graduate School of East-Hest Hedical Science, Kung Hee Universitvi, Yongin-City, Gveonggi-Do 4+49-701, Korea \\ ${ }^{\ddagger}$ Cancer Preventive Material Development Research Center, Kumg Hee Lniversitu, Seoul 130-701, Korea \\ Received June 26, 2009, Accepted Julv 13, 2009
}

Key Wonds: Limonia acidissima. Rutaceae. Dimeric coumarin. Limodissimin A. Anti-neuroinflammatory effect

Previous chemical investigations on Limonia acidissima L. (Rutaceae) have isolated various constituents. including coumarins. steroids triterpenoids. benzoquinones and ty ramine derivatives from different parts of this natural source. ${ }^{1-6}$ Par-

Table 1. 'H and ${ }^{1:} \mathrm{C} N M R$ data of 1 in $\mathrm{CD}_{3} \mathrm{OD}$

\begin{tabular}{clrl}
\hline Position & $\delta_{\mathrm{H}}($ multi, $J=\mathrm{Hz})$ & $\delta_{\mathrm{C}}$ & $\mathrm{HMBC}(\mathrm{H} \rightarrow \mathrm{C})$ \\
\hline 2 & & 163.8 & \\
3 & $6.20(\mathrm{~d}, 9.5)$ & 111.9 & $\mathrm{C}-2, \mathrm{C}-4, \mathrm{C}-10$ \\
4 & $7.84(\mathrm{~d}, 9.5)$ & 146.7 & $\mathrm{C}-2, \mathrm{C}-9$ \\
5 & $7.33(\mathrm{~d}, 8.5)$ & 128.5 & $\mathrm{C}-7, \mathrm{C}-9$ \\
6 & $6.84(\mathrm{~d}, 8.5)$ & 114.8 & $\mathrm{C}-8, \mathrm{C}-10$ \\
7 & & 161.5 & \\
8 & & 114.1 & \\
9 & & 155.4 & \\
10 & & 113.3 & \\
$1^{\prime}$ & $3.06(\mathrm{dd}, 7.5,13.5)$ & 30.2 & $\mathrm{C}-7, \mathrm{C}-9, \mathrm{C}-3^{\prime}$ \\
& $3.16(\mathrm{dd}, 6.0,13.5)$ & 76.3 & $\mathrm{C}-8, \mathrm{C}-4^{\prime}, \mathrm{C}-5^{\prime}$ \\
$2^{\prime}$ & $4.44(\mathrm{dd}, 6.0,7.5)$ & 148.6 & \\
$3^{\prime}$ & & 111.4 & $\mathrm{C}-2^{\prime}, \mathrm{C}-5^{\prime}$ \\
$4^{\prime}$ & $4.68 \mathrm{br} \mathrm{s}, 4.72 \mathrm{br} \mathrm{s}$ & 17.8 & $\mathrm{C}-2^{\prime}, \mathrm{C}-4^{\prime}$ \\
$5^{\prime}$ & $1.86 \mathrm{~s}$ & 163.9 & \\
$2^{\prime \prime}$ & & 112.5 & $\mathrm{C}-2^{\prime \prime}, \mathrm{C}-4^{\prime \prime}, \mathrm{C}-10^{\prime \prime}$ \\
$3^{\prime \prime}$ & $6.18(\mathrm{~d}, 9.5)^{\sigma}$ & 146.2 & $\mathrm{C}-2^{\prime \prime}, \mathrm{C}-9^{\prime \prime}$ \\
$4^{\prime \prime}$ & $7.83(\mathrm{~d}, 9.5)^{\circ}$ & 130.8 & $\mathrm{C}-7^{\prime \prime}, \mathrm{C}-9^{\prime \prime}$ \\
$5^{\prime \prime}$ & $7.45(\mathrm{~d}, 8.5)$ & 114.6 & $\mathrm{C}-8^{\prime \prime}, \mathrm{C}-10^{\prime \prime}$ \\
$6^{\prime \prime}$ & $6.82(\mathrm{dd}, 2.5,8.5)^{\sigma}$ & 163.2 & \\
$7^{\prime \prime}$ & & 103.5 & $\mathrm{C}-6^{\prime \prime}, \mathrm{C}-10^{\prime \prime}$ \\
$8^{\prime \prime}$ & $6.72(\mathrm{~d}, 2.5)$ & 157.3 & \\
$9^{\prime \prime}$ & & 113.4 & \\
$10^{\prime \prime}$ & & & \\
\hline
\end{tabular}

NMR data were obtained in $500 \mathrm{MHz}$ for ${ }^{1} \mathrm{H}$ and $125 \mathrm{MHz}$ for ${ }^{12} \mathrm{C}$. respectively. "Oterlapped signals. ticularly, plenty of interesting coumarins. exhibiting anti-fungal activity have been reported in $L$. acidissima. 'Thanaka', a root paste made from the pulp of $L$. acidissima. is a facial cosmetic to remove small spots and lesions on the skin ${ }^{9}$ We describe herein the isolation and structural elucidation of a new dimeric coumarin, limodissimin A (1), together with four known coumarins (2-5) from further studies on $L$. acidissima ${ }^{\text {li }}$ and their ability to inhibit NO production in LPSactivated BV-2 cells. a microglial cell line.

Limodissimin A (1) was isolated as a yellow gum and showed a fluorescence at UV-365 $\mathrm{mm}$. The molecular formula of 1 was deternined to be $\mathrm{C}_{33} \mathrm{H}_{18} \mathrm{O}_{6}$ from the $[\mathrm{M}+\mathrm{H}]^{+}$peak at $m z 391.1189$ (calcd. for $\mathrm{C}_{23} \mathrm{H}_{19} \mathrm{O}_{6}: 391.1182$ ) in HRFABMS spectrum. The IR spectrum indicated that 1 possessed hydroxyl $\left(3356 \mathrm{~cm}^{-1}\right)$, carbonyl $\left(1660 \mathrm{~cm}^{-1}\right)$ and aromatic ring (1624. 1542 and $1510 \mathrm{~cm}^{-1}$ ) groups. The UV spectrun absorption at 214,258 and $325 \mathrm{~mm}$ showed the characteristics of a 7-oxygen-substituted coumarin for $1{ }^{11}$ The ${ }^{1} \mathrm{H}$ NMR spectrum (Table 1) of 1 displayed two vicinal pairs of typical $\mathrm{H}-3$ and $\mathrm{H}-4$ protons of AX system at $\hat{\delta}_{\mathrm{H}} 6.20$ (1H. d. $J=9.5 \mathrm{~Hz}$, $\mathrm{H}-3) / 7.84(1 \mathrm{H} . \mathrm{d} . J=9.5 \mathrm{~Hz}, \mathrm{H}-4)$ and at $\hat{o}_{\mathrm{H}} 6.18(1 \mathrm{H} . \mathrm{d} . J=$ $\left.9.5 \mathrm{~Hz}, \mathrm{H}-3^{\prime \prime}\right) / 7.83\left(\mathrm{lH}, \mathrm{d}, J=9.5 \mathrm{~Hz}, \mathrm{H}-t^{\prime \prime}\right)$. which predicted that 1 was composed of two C-3 and C-4 unsubstituted coumarin moieties. another vicinal pair of AX system protons at $\hat{\delta}_{\mathrm{H}} 6.84(\mathrm{lH}, \mathrm{d}, J=8.5 \mathrm{~Hz}, \mathrm{H}-6) / 7.33(\mathrm{lH}, \mathrm{d} . J=8.5 \mathrm{~Hz}, \mathrm{H}-5)$ and three aromatic protons of ABX system at $\hat{o}_{\mathrm{H}} 6.72(1 \mathrm{H}$. d, $\left.J=2.5 \mathrm{~Hz}, \mathrm{H}-8^{\prime \prime}\right) .6 .82\left(\mathrm{lH}, \mathrm{dd} . J=2.5 .8 .5 \mathrm{~Hz}, \mathrm{H}-6^{\prime \prime}\right)$ and 7.45 (1H. d. $J=8.5 \mathrm{~Hz}$. $\left.\mathrm{H}-5^{\prime \prime}\right)$. suggesting the substitution pattern and the linkage of 1 . Further signals for two exomethylene protons at $\vec{\delta}_{\mathrm{H}} 4.68\left(\mathrm{lH}\right.$. br s. $\left.\mathrm{H}-4^{\prime} \mathrm{a}\right) .4 .72$ ( $1 \mathrm{H}$. brs. $\mathrm{H}-$ $4^{\prime} \mathrm{b}$ ). one oxygenated proton at $\hat{o}_{\mathrm{H}} 4.4+(1 \mathrm{H} . \mathrm{dd}, J=6.0 .7 .5$ $\left.\mathrm{Hz}, \mathrm{H}-2^{\prime}\right)$, two methylene protons of $\mathrm{AB}$ system at $\overrightarrow{\mathrm{d}}_{\mathrm{H}} 3.06$ (1H. dd, $J=7.5 .13 .5 \mathrm{~Hz}$. H-1'a). $3.16(1 \mathrm{H}, \mathrm{dd} . J=6.0,13.5$

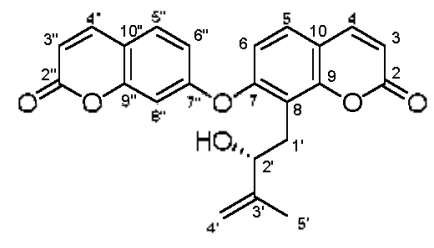

1<smiles>CC(C)=CCc1c(O)ccc2ccc(=O)oc12</smiles>

2<smiles>CC(C)(O)[C@@H](O)Cc1c(O)ccc2ccc(=O)oc12</smiles>

3<smiles>CC(C)(O)[C@H]1Cc2c(ccc3ccc(=O)oc23)O1</smiles>

4<smiles>CC1(C)C=Cc2c(ccc3ccc(=O)oc23)O1</smiles>

5

Figure 1. Structures of compounds 1-5 
$\left.\mathrm{Hz}, \mathrm{H}-\mathrm{l}^{\mathrm{b}} \mathrm{b}\right)$ and one methyl proton at $\delta_{\mathrm{H}} \mathrm{l} .86\left(3 \mathrm{H} . \mathrm{s}, \mathrm{H}-\mathrm{5}^{\prime}\right)$ were observed. The ${ }^{13} \mathrm{C}$ NMR spectroscopic data (Table 1) showed 23 carbon signals. which were composed of two monomeric coumarin units. The NMR resonances of 1 were similar to those of the related coumarins. umbelliferone ${ }^{12}$ and demethylaulraptenol, ${ }^{13}$ suggesting that two coumarin moieties of 1 could be umbelliferone and demethy lauraptenol.

The HMBC spectrum confimed the above suggested structure. The signals of $\mathrm{H}-4\left(\delta_{\mathrm{H}} 7.84\right)$ and $\mathrm{H} \cdot 4^{\prime \prime}\left(\delta_{\mathrm{H}} 7.83\right)$ correlated with $\mathrm{C}-2\left(\hat{\delta}_{C} 163.8\right), \mathrm{C}-9\left(\hat{\delta}_{C} 155.4\right)$ and with $\mathrm{C}-2^{\prime \prime}$ $\left(\delta_{C} 163.9\right) . C-9^{\prime \prime}\left(\delta_{c} 157.3\right)$, respectively and the correlations between $\mathrm{H}-2^{\prime}\left(\hat{\delta}_{\mathrm{H}} 4.44\right)$ with $\mathrm{C}-8\left(\hat{\delta}_{\mathrm{C}} 11+.1\right)$ and between $\mathrm{H}-\mathrm{t}^{\prime}$ $\left(\delta_{\mathrm{H}}+62.4 .72\right)$ with $\mathrm{C}-2^{\prime}\left(\delta_{0} \cdot 76.3\right) . \mathrm{C}-5^{\prime}\left(\delta_{\mathrm{C}} 17.8\right)$ were observed in the $\mathrm{HMBC}$ experiment (Figure 2), allowing a hydroxyl group to be at $\mathrm{C}-2^{\prime}$. These assignments were further supported by NOESY experiment. On the basis of the above findings. the structure of 1 was assigned as limodissimin A (1) [7-[(2"oxo-2H-1-benzopyran-7"-yl)oxy]-8-[2'-hydroxy -3'-methy l-3'buten-l'-yl]-2H-I-benzopy ran-2-one]. The absolute configuration of 1 was determined by a convenient Mosher ester procedure carried out in an NMR tube. ${ }^{1+}$ Analysis of the chemical shift differences between MTPA ester derivatives of 1 ( $1 \mathbf{r}$ and 1s. Figure 2) revealed the $R$-configurated $\mathrm{C}-2$ '. Furthermore. the positive optical rotation value of $1\left([\alpha]_{\overline{5}}^{\hat{5}}+3.8^{\circ}\right)$ was in good agreement with that of related $\left(2^{\prime} R\right)$-hydroxy-coumarin derivatives. 15,16

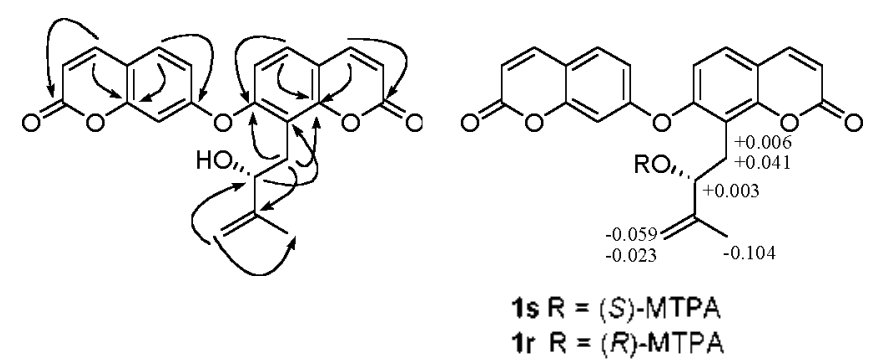

Figure 2. Key HMBC comelations and values of $\delta_{s}-\delta_{R}$ (data obtanied in pyridine-ds) of the MTPA esters of 1 .

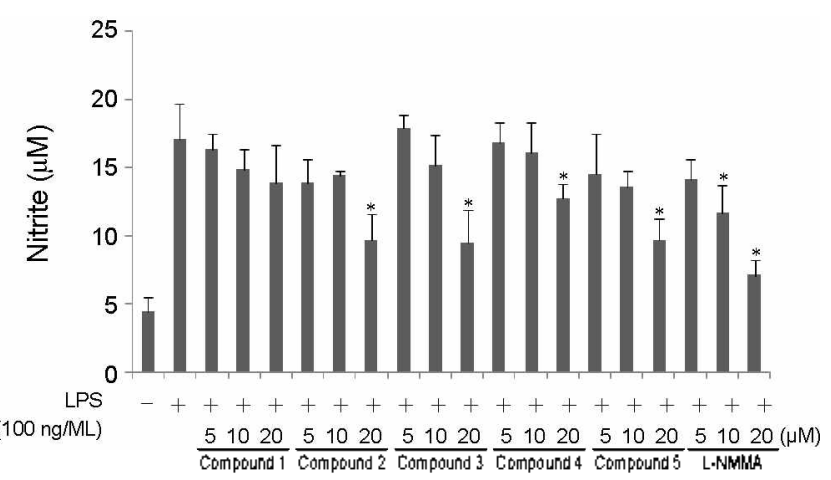

Figure 3. Effects of compounds 1-5 and NMMA on LPS-induced NO production in BV-2 microglia cells. Cells were pretreated with compounds 1-5 and NMMA $(5,10$, and $20 \mu \mathrm{M})$ for $30 \mathrm{~min}$ and then stimulated with LPS ( $100 \mathrm{ng} / \mathrm{mL}$ ) for another $24 \mathrm{~h}$. The culture medium was then collected for a nitrite assay. Nitrate was measured using a Griess reaction. All data were presented as the mean \pm S.E.M of three independent experiments. ${ }^{*} p<0.05$ indicates statistically significant differences compared to treatment with LPS alone.
The known compounds, osthenol (2). ${ }^{17}(2 R)-7$-hy drosy-8(2'.3'-dihydroxy -3'-methỵlbutỵl)-2 $H$-1-benzopyran-2-one (3). ${ }^{18}$ columbianetin $(\mathbf{4})^{19}$ and seselin $(\mathbf{5})^{20}$ were also isolated. Their structures were identified by comparing their spectroscopic data with those in the literature. The isolated known compounds 3-5 were reported from this source for the first time.

We evaluated the inhibitory effects of isolated compounds 1-5 on NO production in LPS-activated BV-2 cells. a microglial cell line. As shown in Figure 3, compounds 2, 3. 4 and 5 significantly inhibited the LPS-induced NO production. with IC 5 values of $22.3,21.6,33.5$ and $23.1 \mu \mathrm{M}$, respectively. Compound 1 did not show the significant inhibitory effect on NO production in ranges from 5 to $20 \mu \mathrm{M}$. In summary. the present study demonstrated that coumarins (compounds 2, 3 . 4 and 5) isolated from L. acidissima exert anti-inflammatory effects in LPS- stimulated microglia cells. These results suggest that coumarins $2,3,4$ and 5 might be good lead compounds to modulate neurological diseases associated with inflammatory processes.

\section{Experimental Section}

General Procedures. Optical rotations were measured on a Jasco P- 1020 polarimeter in $\mathrm{MeOH}$. IR spectra were recorded on a Bruker IFS-66/S FT-IR spectrometer. UV spectra were recorded using a Schimadzu UV-160I UV-Visible spectrophotometer. FAB and HRFAB mass spectra were obtained on a JEOL JMS700 mass spectrometer. NMR spectra, including ${ }^{l} \mathrm{H} \cdot{ }^{1} \mathrm{H}$ COSY HMQC. HMBC and NOESY experiments, were recorded on a Varian UNITY INOVA 500 NMR spectrometer operating at $500 \mathrm{MHz}\left({ }^{1} \mathrm{H}\right)$ and $125 \mathrm{MHz}\left({ }^{15} \mathrm{C}\right)$ with chemical shifts given in ppn (ô). Preparative HPLC was conducted using a Gilson 306 pump with Shodex refractive index detector and Apollo Silica $5 \mu$ column $(250 \times 22 \mathrm{~mm})$. Silica gel 60 (Merck. $70-230$ mesh and 230 - 400 mesh) was used for colunin chromatography. The packing material for molecular sieve column chromatography was Sephadex LH-20 (Pharmacia Co.). Spots were detected on TLC under UV light or by heating after spraying with $10 \% \mathrm{H}_{2} \mathrm{SO}_{4}$ in $\mathrm{C}_{2} \mathrm{H}_{5} \mathrm{OH}(\mathrm{v} / \mathrm{v})$.

Plant Materials. The dried bark of $L$ acidissima was imported from Yangon. Union of Myanmar. in October 2006 and identified by Dr. W. Bae. A voucher specimen (SKKU 200610) was deposited at the R \& D Institute. Miwon Commercial. Co., LTD, Ansan, Korea.

Extraction and Isolation. The dried bark of L. acidissima (3 $\mathrm{kg}$ ) was extracted with $85 \% \mathrm{EtOH}$ three times at $85^{\circ} \mathrm{C}$. The resulting ethanol extract $(250 \mathrm{~g}$ ) was suspended in distilled water (7.2 L) and then partitioned with EtOAc. yielding an EtOAc soluble extract $(50 \mathrm{~g})$. The EtOAc soluble fraction ( 50 g) was separated over a silica gel column. eluted gradiently with $n$-hexane-EtOAc $(10: 1,5: 1,1: 1$, and $0: 1, v / v)$ to afford 12 fractions (Fr. A to Fr. L). Fr. H ( $810 \mathrm{mg}$ ) was separated further over a silica gel column $\left(\mathrm{CHCl}_{3}-\mathrm{MeOH}, 17: 1\right.$, v/v) to give three subfractions (Fr. H1 to Fr. H3). Fr. H2 (450 mig) was separated over a Sephadex LH-20 (Phannacia Co.). using a solvent system of $\mathrm{CH}_{2} \mathrm{Cl}_{2}-\mathrm{MeOH}(1: 1 . \mathrm{v} / \mathrm{v})$ to yield three subfractions (Fr. H2l to Fr. H23). Fr. H23 (120 mig) was separated by preparative HPLC. over $30 \mathrm{~min}$ at a flow rate of 
$2.0 \mathrm{~mL} / \mathrm{min}$ (Apollo Silica $5 \mu$ column; $250 \times 22 \mathrm{~mm} ; 5 \mu$ particle size: Shodex refractive index detector) to obtain 1 ( 8 mg. $n$-hexane-EtOAc $1: 1, v / v) .2(7 \mathrm{mg}, n$-hexane-EtOAc. $1: 1 . \mathrm{v} / \mathrm{v}), 3$ (11 mg. $n$-hexane-EtOAc, $1: 1 . \mathrm{v} / \mathrm{v}), 4\left(6 \mathrm{mg}, \mathrm{CHCl}_{3}\right.$ $\mathrm{MeOH}, 12: 1$, v/v) and $5\left(7 \mathrm{mg}, \mathrm{CHCl}_{3}-\mathrm{MeOH}, 10: 1, \mathrm{v} / \mathrm{v}\right)$.

Limodissimin A (1). yellow gum. $[a]_{\mathrm{D}}^{25}+3.8^{\circ}$ (c 0.08 . $\mathrm{MeOH}):$ IR $(\mathrm{KBr}) v_{\max } \mathrm{cm}^{-1}: 3356,2948,1660,1624,1542$. 1510, 1032. 670: UV $\lambda_{\max }(\mathrm{MeOH}) \mathrm{nm}(\log \varepsilon): 325(4.27), 258$ (w), $21+(4.38)$; FABMS $m z 391[\mathrm{M}+\mathrm{H}]^{-}$: HRFABMS $m z$ $391.1189[\mathrm{M}+\mathrm{H}]^{+}$(calcd. for $\mathrm{C}_{33} \mathrm{H}_{19} \mathrm{O}_{6}: 391.1182$ ): ${ }^{1} \mathrm{H}$ and ${ }^{13} \mathrm{C}$ NMR: see Table 1.

Preparation of the ( $R$ )- and ( $S$ )-MTPA Ester Derivatives of 1 by a Convenient Mosher EsterProcedure. Compound $1(0.7$ $\mathrm{mg}$ ) in deuterated py ridine $(0.75 \mathrm{~mL})$ was transferred into a clean NMR tube $(S)$-(+)- $\alpha$-Methoxy- $\alpha$-(trifluoromethyl)phenỵlacetyl chloride. (5)-MTPA-Cl $(5 \mu \mathrm{L})$ was added into the NMR tube immediately under a $\mathrm{N}_{2}$ gas stream and then the NMR tube was shaken carefully to mix the sample and (S)-MTPA-Cl evenly. The reaction NMR nibe was permitted to stand at room temperature ovemight. The reaction was then completed to afford the $(R)$-MTPA ester derivative (1r) of 1 . In the manner described for 1r. (S)-MTPA ester derivative of 1 (1s) was obtained. The ${ }^{1} \mathrm{H}-\mathrm{NMR}$ spectra of $1 \mathrm{r}$ and $1 \mathrm{~s}$ were measured with the reaction NMR tubes directly. 1s: ${ }^{1} \mathrm{H}-\mathrm{NMR}(500 \mathrm{MHz}$. py ridine- $\left.d_{5}\right)$ : ò $6.251(1 \mathrm{H}$, dd, $J=6.0,7.5 \mathrm{~Hz}$. H-2'a), 5.047 (IH. br s. H-4'a) 4.802 (lH. br s. H-4b). 3.569 (lH. m. H-l'a). $3.5 \mathrm{l} 4\left(1 \mathrm{H}, \mathrm{m} . \mathrm{H}-\mathrm{l}^{\mathrm{b}} \mathrm{b}\right) .1 .958$ (3H. s. H-5 $)$ : FAB-MS $m z 606$ $\left[\mathrm{M}^{-}, 1 \mathrm{r},{ }^{\mathrm{l}} \mathrm{H}-\mathrm{NMR}(500 \mathrm{MHz}\right.$, pyridine- $d s): \delta 6.248(1 \mathrm{H}, \mathrm{dd}, J=$ $\left.6.0 .7 .5 \mathrm{~Hz} . \mathrm{H}-2^{\prime} \mathrm{a}\right) .5 .106$ (1H. br s. H-4'a) +.825 (1H. br s. $\left.\mathrm{H}-4^{\prime} \mathrm{b}\right), 3.528$ (lH, m, H-l'a), $3.508(1 \mathrm{H}, \mathrm{m}, \mathrm{H}-\mathrm{l}$ b), 2.062 (3H. s. H-5'): FAB-MS $m: z 606\left[\mathrm{M}^{-}\right.$.

Measurement of NOProduction and Cell Viability. A murine microglia cell line. BV-2 cells, was stimulated with $100 \mathrm{ng} / \mathrm{mL}$ of LPS in the presence or absence of samples for $24 \mathrm{~h}$. Nitrite in the culture media, a soluble oxidation product of NO, was determined using the Griess reaction. Cell viability was measured using a $3-[4,5$-dimethylthiazol-2-yl]-2.5-diphenyltetrazolium bromide (MTT) assay. ${ }^{21} \mathrm{~N}^{3}$-monomethyl-L-arginine (L-NMMA. Sigma). a well-known NOS inhibitor. was tested as a positive control.

Aclonow ledgments. This work was supported by the R \& D Institute Miwon Commercial. Co. LTD in Korea and the Korea Science and Engineering Foundation (KOSEF) grant funded by the Korea government (MEST) (No. 2009-0063466). The authors would like to thank Mr. Do Kyun Kim. Dr. Eun Jung Bang. and Dr. Jung Ju Seo at the Korea Basic Science Institute for the measurements of NMR and MS spectra.

\section{References}

1. Ghosh, P.; Sil, P; Majumadar, S. G.; Thakur, S. Phytochemisty 1982, 21, 240.

2. Patra, A.; Misra, S. K.: Chaudhuri, S. K. J. Indian Chem. Soc. $1988,65,205$

3. Bandara, B. M. R.; Gunatilaka, A. A. L.; Wijeratne, E. M. K.; Adikaram, N. K. B. Planta Hed. 1988, 54, 374.

4. MacLeod, T. K.; Moeller, P. D. R.; Bandara, B. M. R.; Gunatilaka, A. A. L.; Wijeratne, E. M. K. J Nat. Prod 1989, $52,882$.

5. Ghosh, P.; Ghosh, M. K.; Thakur, S.: Datta, J. D.; Akihisa, T.; Tamura, T.; Kimura, Y. Plytochemistry 1994, 37, 757.

6. Ghosh, P.; Sil, P.; Das, S.; Kokke, W. C. M. C. Kolke, W. C. M.; Akihisa, T.; Shimizu, N.; Tamura, T.; Matsumoto, T. J. Nat. Prod. 1991, 54, 1389.

7. Kithsiri Wijeratne, E. M.; Ratnayake Bandara, B. M.: Leslie Gunatilaka, A. A.; Tezuka, Y.; Kikuchi, T. J. Not. Prod. 1992, 55,1261 .

8. Adikaram, N. K. B.; Abhayawardhane, Y.; Bandara, B. M. R.; Gunatilaka, A. A. L.: Wijeratne, E. M. K. Plant Pathol. 1989, 38 , 258.

9. Chopra, R. N.: Nayar, S. L.: Chopra, I. C. Glossany of Indian Nedicinal Plants; C. S. I. R., New Delhi, 1956; p 154.

10. Kim, K. H.; Lee, I. K. Kim, K. R.; Ha, S. K.; Kim, S. Y ; Lee, K. R. Planta Med. $2009,75,1146$.

11. Xu, R. S. Namal Products Chemistrn. Scientific Press: Beijing, 1993 : 650 .

12. Razdan, T. K.; Qadri, B.; Harkar, S.; Waight, E. S. Phvtochentistry 1987, 26,2063.

13. Barik, B. R.; Dey, A. K.; Das, P. C.; Chatterjee, A.; Shoolery, J. N. Phtochemist $1983,22,792$

14. Su, B. N.: Park, E. I.: Mbwambo, Z. H.: Santarsiero, B. D.: Mesecar, A. D.; Fong, H. H. S.; Pezzuto, J. M.; Kinghorn, A. D. J. Not. Prod. 2002, 65, 1278 .

15. Burke, B. A.; Parkins, H. Phvtochentistry 1979, 18, 1073

16. Ceccherelli, P.; Curini, M:; Marcotullio, M. C.; Madruzza, G.; Menghini, A. J. Kat. Prod. 1990, 53,536.

17. Riviere, C.; Goossens, L.; Ponmery, N.; Foumean, C.; Dellelis, A.; Henichart, J. P. Kat. Prod. Res. 2006, 20, 909.

18. Lemmich, J. Phtochemistry 1995, $38,427$.

19. Afek, U.: Carmeli, S.; Aharoni, N. Phntochemisty 1995, 39 . 1347

20. Furukawa, H.: Ju-Ichi, M.: Kạilura, I.: Hirai, M. Chem. Pham. Bull. 1986, 34, 3922 .

21. Sargent, J. M.; Taylor, C. G. Br. J. Cancer 1989, 60, 206. 